\title{
HUMAN RIGHTS AND STRONG INSTITUTIONS: A STUDY OF AMNESTY INTERNATIONAL IN NIGERIA
}

\author{
EBIERI FAVOUR ${ }^{1}$, SHERIFF FOLARIN ${ }^{2}$
}

\begin{abstract}
Human right is a topical issue globally but attaining it has remained very difficult. Every day, people around the world face different forms of dehumanizing treatment from their governments, multinationals and other groups. For decade too, strong institutions have emerged to fight for the rights of the voiceless and the weak. One of these institutions is Amnesty International (AI). This paper examines the activities of Amnesty International in the promotion and protection of human rights vis-a-vis the nature of operations, contributions and challenges in Nigeria. The paper adopts desk research design, which is based on secondary sources from journals, books and other printed materials. Findings revealed that AI has significantly contributed to the promotion of human rights in Nigeria through different approaches such as advocacy/campaign, governance peer review, shaming-and-naming approach, and support for domestic civil rights groups, among others. However, findings also showed that the main challenges of AI are the negative perceptions of some sections toward the organization as a tool for promoting western ideology and the low awareness and involvement of individuals at the grassroots in developing nations like Nigeria. The paper recommends that the organization intensifies its promotional activities in a manner that would improve its reputation as well as help to educate and provide access for engagement of locals in developing countries.
\end{abstract}

Keyword: Amnesty International, Human Rights, Strong Institutions

Summary: 1. Introduction. 2. Methodology. 3. Conceptual Clarification, 3.1. Concept of Human Rights. 4. Concept of Strong Institutions. 5. Perspectives in Literature. 6. Theoretical Construct. 7. Role of Ai in Strengthening Human Rights Base in Nigeria. 7.1. Modes of Operation, 7.2. Challenges and Criticism of Amnesty International. 8. ConCLUSIONS. 9. ReCOMMENDATIONS.

\section{INTRODUCTION}

Human rights and strong institutions are essential ingredients in every society to ensure justice, encourage respect and tolerance for citizens and help build a sustainable society. Injustice against humanity by other humans and systems is a global issue from time immemorial. Similarly, the desire to promote human rights and strong and accountable institutions is not a new subject.

In the $21^{\text {st }}$ century following the Universal Declaration of Human Rights (UDHR) in 1948, following the end of Second World War and the horrific Holocaust, and Cold War that left the world in disarray, human rights issues took the global stage and forced the world to commit to prevention of any reoccurrence of such horrors and atrocities of

\footnotetext{
${ }^{1}$ Department of Political Science \& International Relations, Covenant University Ota, Nigeria (jones. favour@ymail.com)

${ }^{2}$ Department of Political Science \& International Relations, Covenant University Ota, Nigeria
} 
the past (Global Citizenship Commission, 2016). This development increased awareness of the equality and universality of every individual and the creation of strong institutions to help maintain and enforce it (Ramcharan, 2015). The UN Universal Declaration of Human Rights is recognized as the pioneer for the promotion and protection of human rights, thus putting increased demands on national governments to protect the rights of their citizens from any form of abuse through the creation of institutions that uphold the law (Krasner 2001).

It has become expedient and normal for all countries of the world to domesticate the UN's UDHR in their constitutions; thus, human rights are often expressed in nations' constitutions, regional treaties and other sources across the world (UNDC, Guidance, 2011). Despite this development, evidence abounds of increasing cases of human rights abuses around the world. Reports by Amnesty International (2008) indicated that decades after the adoption of the UDHR, individuals still suffer a gross violation of human rights in many countries through detention, unfair trial and physical attacks among other forms of abuse.

Similarly, in Nigeria, there are documented cases of human rights abuses such as rape, unlawful detention, killing of innocent people, environmental pollution, among other abuses which are motivated by politics, terrorism such as Boko Haram; and activities of multinationals especially in the Niger-Delta. Other instances are violations occasioned by religious fanaticism, ethnic bigotry and police and military brutality, which are rarely investigated (Onwuazombe, 2017). This shows that national governments around the world especially in developing nations like Nigeria have not significantly lived to the expectations or demands of the United Nations UDHR which they are signatories.

The inability of state actors to ensure the protection of human rights throughout the world has brought several human rights groups or institutions and civil societies who are dedicated to promoting and protecting the rights of individuals. According to Jacobs and Maldonado (2005) human rights' groups or exists at the domestic and international levels. At the domestic level, such groups often act in opposition to formal government actors and International level; they opined that human right groups are self- formulated activism group that assumes the role of a united act throughout the world in defense of human rights. Example of such institutions includes Human Rights without Frontiers, Human Rights Watch, Human Rights Action Center and Amnesty International.

For this study, Amnesty International will be the focus, as it is the largest human rights protector or institution in the world. The ultimate goal of the Amnesty International is a world in which all individuals have access to human rights as stated in the UDHR (Statute of Amnesty International, 2005). With a plethora of cases of human rights violation throughout the world, the activities of human right institutions like Amnesty International must be examined.

The specific objectives of this paper are as follows:

i. To examine the activities of Amnesty International in the fight for Human rights and strong institutions in Nigeria. 
ii. To assess the contributions of Amnesty International toward the actualization of the Universal Declaration of Human rights.

iii. To examine the challenges of Amnesty International in their effort toward promoting human rights and strong institutions in Nigeria.

The study is further guided by the following research questions:

i. How does Amnesty International engage in the fight for Human rights and strong institutions in Nigeria?

ii. What are the contributions of Amnesty International toward the actualization of the Universal Declaration of Human rights?

iii. What are the challenges facing Amnesty International in their effort toward promoting human rights and strong institutions in Nigeria?

\section{Methodology}

This study adopts the qualitative research method. Within the qualitative approach, the study further used desk research design. The desk research design involves the collation and synthesizing of secondary sources of data or existing research or published materials about a particular subject matter to gain a broader understanding. Thus, desk research design goes beyond literature review but critical examination of previous findings in line with given research questions. Based on this, this study used previous works and publications from different sources about the activities of Human right defenders especially Amnesty International in the actualization of the UDHR.

\section{Conceptual Clarification}

\subsection{Concept of Human Rights}

There is no universal definition of what constitute human rights. Several scholars and institutions have proffered different definitions but which point in a similar direction. According to Donnelly (2008), human rights imply the rights one has because one is a human being. The definition placed all human on the same footing but have not given us in-depth descriptions of the privileges all human beings need to enjoy or hazard human need to be protected from. In his submission, Onwuazombe (2017) defines human rights as those rights which all human beings are given by virtue of humanity, he further identifies such rights as the right to life, freedom of thought, the dignity of the human person, fair hearing and personal freedom, conscience and religion. He describes further that these rights are natural, sacred and permanent and when denied is a violation of the law.

Human rights are featured in constitutions of nations and have received significant attention in the media and global discourse. However, the implementation of 
human rights has always been an issue of concern to the global family. It is important to note that no country can claim to have provided absolute human rights for its citizens, the degree at which human rights are implemented varies from country to country. In authoritarian systems, human rights laws and legislations are suspended for political reasons and the issue of sovereignty of nations has always been a bottleneck on United Nations as a "global government" to effectively force national governments to promote human rights. Therefore, human rights promotion and protecting are left in the hands of civil societies like Amnesty International.

\section{Concept of Strong Institutions}

The notion of Strong institution emanated from the Sustainable Development Goal 16; Peace, Justice and Strong institution. Following that notion, strong institution refers to operational state organization with responsible institutions, transparency and the rule of law. They form the basis of good governance including anti-corruption measures and are essential because it encourages development in society (Government Office of Sweden, 2015).

Adam (2017) describes a strong institution as state accountability and its importance to citizens, who should be able to hold government accountable for their promises and request effective policies to address core development issues.

Strong institution refers to transparent and accountable institutions put in place to ensure participatory decision-making and responsive public policies that leave no one behind, and whereby citizens have unfettered access to justice and the rule of law, without which there can be no sustainable development (Okai, 2019).

\section{Perspectives in Literature}

Human rights and strong institutions which are accountable and transparent are the focus of Amnesty International. These have attracted scholarly scrutiny. Many forms of research have been conducted on the subject matter leading to many findings and postulations. Schneider (2002) opines that human rights groups play the most visible role in solving global human rights. Alice, Karen, Danna and James Savage (2013) concur that since 1946 there has been growing recognition of the significance of human rights and that various institutions such as government and civil society actors have developed various protection mechanisms to protect and promote human rights. However, the development according to the authors has not effectively end human abuse as many continue to suffer from human rights violations and abuses by state and non-state actors, such as the police, military, other security services and armed groups among others. It, therefore, means that there is still a long way in actualizing the Universal Declaration of Human rights and that Human rights groups such as Amnesty International has more responsibilities. Ban Ki-moon (2016), attested to this assertion when he argued that certain governments hinder their citizens from exercising their human rights which is a violation of human rights and disassembling judicial institutions that limit executive power. 
According to Omede and Rufai (2014), Human right groups are agents of development in any nation because they play a crucial role in political, social, and economic development activities. They further argued that the transformation of any society or system, particularly the developing societies like Nigeria depend on the effectiveness and efficiency of non-governmental organizations. One of the major roles played by non-governmental organizations which contribute to the development of societies is the protection of human rights and accountability of government institutions. Developing nations are often associated with abuse of human rights, a hindrance to freedom of speech which is a catalyst for human rights, absences of rule of law, corruption and lack of transparency and accountability of institution, but non-governmental organizations like Amnesty International have continued to serve as the voice of the voiceless in nations of the world especially in developing countries and improve the quality of governance and the capacity of governments to apply the principles of accountability, transparency and openness by so they serve as a correctional mechanism to check the excesses of government to avoid abuse to the human right at different dimensions.

Similarly, Brett (as cited in Schneider, 2000) assert that the effective participation of non-governmental organizations like Amnesty International is important in the promotion of human right in that they empower the arrangement bodies to work proficiently and compellingly. They help in investigating states party's report at the national level; giving information to treaty bodies; aiding the spread of information, and adding to the usage of proposals by the bargain treaties bodies.

The West Asia-North Africa Institute (WANA, 2018) concurs that civil society groups play a key role in monitoring human rights policies and legislation adopted by government and decisionmakers in various countries, they criticize practices that are antigovernment and advocate for the protection of the citizens' right at all levels. Similarly, Zafarullah and Rahman (2002) observed that in the past few decades, Human rights organizations have proliferated the world playing a key role in promoting human right by serving as the voice for the mistreated and the oppressed, sorting out and making an aggregate move in the interest of the oppressed.

They categorically state that the intensification of human rights advocacy was motivated by the expansion of human rights issues which have become agenda of social, economic and political debate and secondly the rise of strong and accountable nongovernmental organizations (NGOs) like the Amnesty International with strong global support and presence.

Reflecting on the performance of strong human right groups which have proliferated the world particularly in Bangladesh, Zafarullah (as cited in Zafarullah and Rahmah, 2002) explained that in Bangladesh, democratic practices and individual freedom have been hard to set up because of continuous military involvement in state issues. He included that the nation is beset by the absence of political agreement, feeble government authorities, and undesirable methods of political challenge, undemocratic political group structures, political and governmental support, and frail local administration. All of which created an absence of equivalent access to equity, and violation of human rights in the country. This 
exposition by Zafarullah indicates that in many countries in Asia, human right abuses are still high after decades of the Universal Declaration of Human rights and continuous activities of human rights organizations like Amnesty International.

Chukwuemeka (2016) asserts that strong human right groups have shown its ability to balance the activities of international and national government's efforts in the promotion of human right across the world, especially in war-torn African countries. According to him, strong human right defenders like Amnesty International have developed an in-depth knowledge of the extent human right protection, abuses and patterns in many countries as well as using their expertise in working closely with local civil society groups to promote the right of members of different communities in many African countries. However, the West Africa Network for Peace-building (2014) explained that democratization remains a protest to maintaining peace and stability in Africa and that more than 10,000 citizens in West African have died in political conflict over the years aside different kinds of other dehumanizing experiences people are facing especially during elections. For instance, in Nigeria, the 2019 General elections came with a record of various forms of human rights abuses across the nation. In Rivers State, there were cases of armed security agents who perpetrated the assault on electorates; many people were arrested, detained unlawfully concerning the elections.

Eseyin and Udoh (2015) in a study titled "When Rights Violate Rights: International Protection of Human Rights, Some Necessary Considerations" argues that defence of human rights is an essential component in a democratic government and that this conviction made issues important in the international law by international and regional instruments, and domestically by national law. They, however, argued that during an individual's activities, human rights are been abused in different forms. They focused on the argument that some human rights by themselves is infringement or violations of other rights, thus making the fight for human rights a complex task.

The literature above shows Human Rights Organizations have been growing in number and prominence around the world and that they have played significant roles as protectors and promoters of human rights. Despite a plethora of studies about human rights and human rights organizations, there is currently a paucity of research investigating the impact of specific organizations especially prominent organization like Amnesty International. Most studies on Human right organizations tend to lump all the organizations together and draw generalization or categorized them into domestic and international organizations. This study takes a departure from the norm by dedicating attention to Amnesty International.

\section{Theoretical Construct}

This study implements a theoretical approach which portrays the role of Amnesty International in upholding human rights and strong institution in Nigeria through the structural functionalism theory. Structural functionalism posits that there is the existence of a social structure within a system and that different aspects of social structure and social organization are functionally related to one another so that what happens in one part of 
society affects and is shaped by what happens in others. This means that relationships between members of society are organized in terms of rules (Potts, 2015).

The structures of the political system concerning human rights and strong institutions such as the government are not distinct and properly patterned, however, despite this, they are of huge importance. The mandates of these institutions often overlay in realism; thus, structural functionalism enables the researcher to have a clear notion concerning the role of Amnesty International in realizing the human rights and strong institutions in Nigeria

\section{Role of AI in Strengthening Human Rights Base in Nigeria}

The name Amnesty International echoes human right activism. Eckel (2014) opines that Amnesty International brought to fore how private initiatives can play a significant role in civil human rights engagement. In this regard, Amnesty International has served as a driving force behind international human rights politics. He added that there are several groundbreaking records of the role Amnesty International played in exerting pressure on government and persons to ensure that human rights are observed in policies and actions.

In Nigeria, the activities of Amnesty International became prominent during the military regime of Ibrahim Babangida, although reports on Nigeria were made in earlier years during the Civil War activities became more active during the military regime and till date. AI embedded its basic principles which are to form a global community of human rights defenders with the principles of international solidarity in Nigeria and responded to every single human right abuse in the country. The scope of operations for Amnesty International in Nigeria includes; ending all form of violence against women and children, protection of child right, ensuring institutions are accountable, ending all form of torture, protecting the civic space and improving the functioning platform for human right activists, guarantee freedom of expression, abolishing the death penalty and end-all death sentences enforced disappearances and extrajudicial executions, secure economic, social and cultural rights. These areas of focus for Amnesty International in Nigeria are because of the rising report in human right violation and lack of accountability of government institution in upholding human right and rule of law (Amnesty International, 2019)

Amnesty International 2015 report shows that several officials of the Nigeria Police Force and SARS officers have been involved in cases of forced disappearance, killings, and unlawful detention (Amnesty International, 2015). These acts taint the image of state security services that are expected to protect citizens and reveal the extent of human rights abuse in the country (Balogun and Baiden, 2016). For consecutive years these continuous rises of human right violation and abuse of government institution in Nigeria which has been documented by Amnesty International in their yearly report and the role they have a place in trying to avert these issues have been innumerable. 


\subsection{Modes of Operation}

There is an array of techniques which Amnesty International used in its campaign to promote and protect human rights. As stated by Bardarova Jakovley, Serafimova \& Loteski (2013), these include the following:

Letter campaigns: One of the techniques employed by Amnesty International to press demands for the human right is letter campaigns. In this regard members sign, customized letters are sent to government officials and policymakers convincing them to amend the laws towards persons whose rights are violated, this was seen in the case of the letter submitted by Amnesty International in Nigeria to the Presidential Investigation Panel on the compliance of armed forces with human right obligation and its rules of engagement. This letter further stated that from 2012-2017 Amnesty International Nigeria has sent 66 letters to the Nigerian authorities and received 15 responses (Amnesty International, 2017). With the development of information technologies such as social media sites like Facebook and Twitter, letter campaigns are very flexible as citizens and registered members of Amnesty International can access platforms where they can easily sign for letters and take part in the campaigns of their choice. Support for Mass Public Demonstrations: Basically, Amnesty International hardly engage in a direct public demonstration, however, the organization provides support to groups that protest peacefully to press issues that pertain to human rights. In this sense, Amnesty International complement efforts of groups in pursuit of goals of human rights such as the right to work, protection against all kinds of maltreatment by government, among others. For instance, Amnesty Nigeria has condemned Nigeria's crackdown on journalist protester stating that this act obstructs the freedom of expression which is a necessary right for a democratic society like Nigeria. Another example was the demonstration on September 2019 which called for the release of the Leader of the Islamic Movement in Nigeria, Sheikh Ibrahim Al-Zakzaky, who has been detained since December 2015 without trial was supported by Amnesty International (Sahara Reporters, 2016).

Targeted campaigns: This technique used different communication channels such as mass media and news media in which the organizations make press releases, face to face communication, and letters, and communiqué, opinion leaders among others to enlighten authorities about the outcome of their investigations as well as recommendations regarding human right issue or phenomenon. Thus, target campaigns unlike letter campaign are not meant to put pressure on government or decision-makers but provide useful information for sound judgment and decision-making process. Over the years, Amnesty International has built a reputation as one of the most credible sources of for leader information about human right issues around the world, this information comes as yearly reports which are written for every country which Amnesty International operates it. In Nigeria, the yearly reports have been useful to government and citizens in pinpointing the areas of human right violations and have also drawn the attention of international bodies which help to maintain the human right and strong institution.

Training of Local Groups: Amnesty International has been involved in training local groups to help maintain peace, stability and uphold human right in the society. 
During the Niger Delta crisis Amnesty International Program included transformational training that involves education and vocational skills acquisition to help integrate the exmilitants (Tobor and Obudo, 2017). These training are meant to equip local organizations for effective human right promotion and protection. Such sessions also serve as a platform for Amnesty International and Local Activists to develop collaboration for effective sharing of data.

Provision of Human Rights Education to Citizens: Amnesty International believes that the fight for human right requires the provision of sound education regarding human right among citizens. Where people are knowledgeable about their rights, they are more likely to stand to protect such right. Based on these understanding Amnesty International creates different platforms in which the citizens are provided with useful information about human right as enshrined in their nation's respective constitutions as well as the Universal Declaration of Human Right. The organization equips the people with the knowledge of the process of reporting human rights abuse among others. The education is provided through the organization's various platforms especially websites as well as volunteers in different countries which includes and is accessible to Nigerians.

Lobbying: This is a deliberate and systematic approach to influence policymakers such as legislators and other public and private leaders to support a course (human right) in their policies. Lobbying is one of the major techniques employed by Amnesty International. The first act of lobbying in Nigeria was the establishment of its office in Abuja. A former director, of Amnesty International Nigeria, stated the establishing the office will enable them to campaign harder, shout louder and deliver research and analysis into human rights abuses more rapidly than we could before".

Shaming and Naming: Another popular strategy employs by Amnesty International in the fight toward promoting human rights around the world is called "shamming and naming". This tactic entails damaging the reputation of human right abuses in the eyes of relevant institutions through massive condemnation (Scoble \& Wiseberg 1974). Amnesty International Nigeria has engaged in the act of calling out human right violator which include certain government institutions. In June 2019, the organization called out the Nigerian Military for torturing civilian which was a violation of the Human rights. The organization claimed that the victims of torture did not get justice and that the judicial system was unable to bring the culture to impunity to an end. On the 5th of August 2019, the organization called out the Nigerian authorities to investigate the deaths of three Islamic Movement in Nigeria (IMN) members who died in police custody. These methods of naming and shaming help decrease the number of the human right violation.

\subsection{Challenges and Criticism of Amnesty International}

Despite the significant role Amnesty International is playing in Nigeria from 1967 to date, the organization is not without some criticism and challenges which have continued to affect the viability of the organization in the fight against human right abuse. One of 
the major criticisms against Amnesty International is the perception that the organization is western-centric (Conor, 2009). This implies that the organization is driven by western ideologies especially as it relates to what constitute human rights. It is important to note that western cultures are often a subject of resistance in other worlds especially in the Middle East and Asia, thus, the activities of Amnesty International in such cultures are looked with some suspiciousness. In many of such country's membership for the organization and support is very low.

Another challenge Amnesty Nigeria is facing is the recurrent demand by the citizen and government authorities for the organization to leave Nigeria. In August 2019, the organization was accused of being sponsored by the opposition party and taking sides with the nation's enemies. The protest was a result of rumours that they planned a nationwide protest by a coalition of civil organization. The protest tagged "Revolution Now" was supposed to hold August 5 across the country. Amnesty International, however, said they will not be threatened and will continue to fight for human rights and hold government accountable (Adepegba and Akinkuotu, 2019).

Another challenge facing Amnesty International and indeed other international human right groups is their lack of authoritative capacities. The Universal Declaration on Human Right is not binding on the Nigerian laws. Amnesty International can only draw the attention of the Nigerian government and international communities to issues of human rights abuses. Sometimes, the Nigerian government and regimes are very slow in taking actions, hence, requires more time and resources on the side of the organizations. The plethora of such cases might significantly slow down the progress of Amnesty International.

\section{Conclusions}

Implementing human rights and maintaining strong institutions is an important issue that cannot be left in the hands of government because government who supposed to be protectors of human life and dignity are often the top abusers of such right through various actions and inactions. This phenomenon clearly shows the significant place of human right organizations. Today, human right groups like Amnesty International remain specialized institutions equipped and involve in global monitoring of human right issues.

This paper has provided some insight on the activities of Amnesty International in Nigeria, the paper observed that since the emergence of organizations in Britain in 1967, the organization has contributed to the accountability of institution and of promotion of human rights in different dimensions such as the right to life, protection against torture and economic right among others in Nigeria. Despite the challenges and criticism levelled against Amnesty International by some sections, there is no debate that Amnesty International today remains the strongest institution and global leader in human rights promotion and protection. 


\section{RECOMMENDATIONS}

Based on the observed challenges and criticism facing Amnesty International, this paper puts forward the following recommendations:

i. Amnesty International should do more around image management and establish a firm relationship with the Nigerian government and other places where the organization is seen as a tool for promotion of western ideologies.

ii. There is also a need for Amnesty International to create more awareness and knowledge of its activities in grassroots areas of developing countries like Nigeria. This is because the top-down approach to fight for human rights is not a viable strategy. Locals need to understand the ideals of Amnesty as well as have easy access to engagement.

\section{REFERENCES}

ADAMS, B. (2017). Spotlight on Sustainable Development 2017; Reclaiming Policies for the Public: Privatization, Partnership, Corporate Capture, and Their Impact on Sustainability and Inequality- Assessments and Alternatives: Report by the Civil Society Reflection Group on the 2030 Agenda for Sustainable Development.

ADEPEGBA, A. and AKINKUOTU, E. (2017). Protesters ask Amnesty International to leave Nigeria. https://punchng.com/protesters-ask-amnesty-international-to-leavenigeria/

ALICE M. N. KAREN, B. DANNA, I. \& JAMES, S. (2013). A Research Agenda for the Protection of Human Rights Defenders, Journal of Human Rights Practice, 5 (3), 401-420. https://doi.org/10.1093/jhuman/hut026

AMNESTY INTERNATIONAL (2008). European Union: Rising to the Challenge of Protecting Human Rights Defenders. Retrieved December 12, 2020 from https:// www.amnesty.org/download/Documents/52000/eur010092008eng.pdf

AMNESTY INTERNATIONAL (2015). Nigeria: Letter Submitting Amnesty International's Memorandum to The Presidential Investigation Panel on Review of Compliance of Armed Forces with Human Rights Obligations and Rules of Engagement. https://www.amnesty.org/en/documents/afr44/7074/2017/en/

AMNESTY INTERNATIONAL (2017). Human Rights Defenders under threat-A Shrinking Space for Civil Society. London: Peter Berenson House.

AMNESTY INTERNATIONAL (2019). "Nigeria: Human Rights Agenda". Retrieved January 2020 from http://www.amnesty.org/en/documents/afr44/0431/2019/en/

BALOGUN, O. and BAIDEN, R. (2016). Promoting Peace, Justice and Strong Institutions as Enablers for Inclusive Sustainable Development in West Africa. West Africa Civil Society Institute Journal, 5(7) pp. 1-10. 
BARDAROVA, S., JAKOVLEV, Z., SERAFIMOVA, M., \& KOTESKI, C. (2013). The Role of Amnesty International in Protecting Of Human Rights.

BUCHANAN, T. (2004). Amnesty International in Crisis, 1966-7, Twentieth-Century British History 15, No. 3, 267-289.

CHUKWUEMEKA B. E. (2016). The Role of CSOS in Promoting Human Rights Protection, Atrocities Prevention, and Civilian Protection in Armed Conflicts, Global Responsibility to Protect 8 (2016) 249-269. https://doi. org/10.1163/1875984X-00803009

CONOR, F. (2009). Beware Human Rights Imperialism," The Guardian, June 23, https:// www.theguardian.com/commentisfree/2009/jun/23/human-rights-imperialismwestern-

ECKEL, J. (2014). The International League for the Rights of Man, Amnesty International, and the Changing Fate of Human Rights Activism from the 1940s through the 1970s, Humanity Summer, 1 (2), 182-214. https://doi.org/10.1353/hum.2013.0014

ESEYIN, M. \& UDOH, S.E. (2015). When Rights Violate Rights: International Protection of Human Rights, Some Necessary Considerations, International Journal of Humanities and Social Science Vol. 5, No. 6(1), 78-87.

GLOBAL CITIZENSHIP COMMISSION (2016). The Universal Declaration of Human Rights in the $21^{\text {st }}$ Century, The Universal Declaration of Human Rights in the 21st Century: A Living Document in a Changing World. New York: Open Book publishers.

GOVERNMENT OFFICE OF SWEDEN (2015). "Goal 16: Peace, Justice and Strong Institutions" https://www.government.se/government-policy/the-global-goalsand-the-2030-Agenda-for-sustainable-development/goal-16-peace-justice-andstrong-institutions/

JACOBS, J. E., \& MALDONADO, M. (2005). Civil Society in Argentina: Opportunities and Challenges for National and Transnational Organisation. Journal of Latin American Studies, 37(1), 141-172. https://doi.org/10.1017/S0022216X04008557

KI-MOON, B.(2016).UN@70-Human rights at the centre of the global agenda. Retrieved from http://www.un.org/apps/news/story.asp?NewsID=54444\#.WhQrBracZxi

KRASNER, S. D. (2001). “Sovereignty” Foreign Policy 122 (January-February): 20-29.

UNITED NATIONS GUIDANCE NOTE (2011). Promotion and protection of Human Rights, Regional and Global Core Human Rights Treaties, Geneva: United Nations.

OKAI, A. (2019) Opinion: SDG 16 is an accelerator for the entire 2030 Agenda. https:// www.devex.com/news/opinion-sdg-16-is-an-accelerator-for-the-entire-2030agenda-95289

OMEDE, A.J \& RUFAI, B.A. (2014). The Impact of Civil Society Organizations on Sustainable Development in Developing Countries: The Nigerian Experience, An International Multidisciplinary Journal, Ethiopia Vol. 8 (1), 205-227 
ONWUAZOMBE, I. (2017). Human Rights Abuse and Violations in Nigeria: A Case Study of the Oil-Producing Communities in the Niger Delta Region," Annual Survey of International \& Comparative Law, 22.

POTTS, R. (2015) Exploring the Usefulness of Structural-Functional Approaches to Systematically Assess the Functionality of Governance Arrangements for Natural Resource Management and Planning in Two Australian Case Studies.

RAMCHARAN, B. G. (2015). Contemporary Human Rights Ideas: Rethinking Theory and Practice. London: Routledge. https://doi.org/10.4324/9781315751221

SAHARA REPORTERS (2016) Amnesty International Condemns Nigeria's Crackdown on Journalists' Protest. http://saharareporters.com/2016/09/29/amnesty-internationalcondemns-nigerias-crackdown-journalists-protests.

SCHNEIDER, V. (2000). The Social Capital of Amnesty International, Paper prepared for the Workshop 'Voluntary Associations, Social Capital and Interest Mediation: Forging the Link' ECPR Joint Session of Workshops, Copenhagen.

SCHOLTE, J.A. (2001). Civil Society and Democracy in Global Governance. \| CSGR Working Paper No. 65/01, University of Warwick. Available online at http:// www2.warwick.ac.uk/fac/soc/csgr/research/workingpapers/2001/wp6501.pdf.

SCOBLE, H. M., \& WISEBERG, L. S. (1974). Human Rights and Amnesty International. The Annals of the American Academy of Political and Social Science, 413(1), 11-26. https://doi.org/10.1177/000271627441300103

TOBOR, J.O and ODUBO, F. (2017) Amnesty Program as a Peacebuilding Initiative in Niger Delta, Nigeria. Arts and Social Sciences Journal. J 8: 272. https://doi. org/10.4172/2151-6200.1000272

WEST AFRICA NETWORK FOR PEACEBUILDING (WANEP) (2014). Transitions and Tensions in West Africa: Building on the Strength and Bridging the Gap in the ECOWAS Protocol on Democracy and Good Governance', wanep Policy Brief, November.

ZAFARULlAH, H. \& RAHMAN, H. (2002). Human Rights, Civil Society and Nongovernmental Organizations: The Nexus in Bangladesh, Available at: http://muse.jhu.edu/journals/hrq/summary/v024/24.4zafarullah.html. https://doi.org/10.1353/hrq.2002.0055

Received: June $30^{\text {th }} 2020$

Accepted: September $2^{\text {nd }} 2020$ 